\title{
GENRE-BASED APPROACH TO TEACHING SPEAKING OF DESCRIPTIVE TEXT (A CASE STUDY AT A RURAL JUNIOR HIGH SCHOOL IN SOUTH WEST NUSA, INDONESIA)
}

\author{
${ }^{1}$ Ahmad Nahid, ${ }^{2}$ Muchlas Suseno, ${ }^{3}$ Hanip Pujiati, ${ }^{4}$ Juanda \\ ${ }^{1,2,3}$ Universitas Negeri Jakarta, Indonesia \\ ${ }^{4}$ Universitas Samawa, Sumbawa \\ E-mail: ahmadnahidbjm@gmail.com
}

\begin{abstract}
This tudy aims to examine the effectiveness of Genre Based Approach in teaching students' speaking of descriptive text and to investigate the improvement, if any, of junior high school students in their speaking of descriptive genre. To achieve those purposes, both quantitative and qualitative research were utilized. Specifically, one post-test only quasiexperimental design was chosen to achieve the first aim, while case study was utilized to answer the second research purpose. To collect the data, non-participant observations and students' speaking test were conducted. The data from observation were then analyzed using inductive analysis while the students' speaking test was proceed using statistical calculation through t-test and also analyzed using the genre framework analysis of descriptive text. The result reveals that GBA is effective to develop students' speaking descriptive text and the improvement of students is seen from the social function, text organization and linguistic features of the text. Additionally, this study suggests that EFL teachers use GBA to teach other types of text.
\end{abstract}

Keywords: Descriptive text, Genre Based Approach

\section{INTRODUCTION}

Speaking is assumed as a complicated skill to master (Harmer, 2007). This is due to the complexity of any aspects of speaking including pronunciation, vocabulary, the content of what is spoken, and the structure as well as other components which must be in harmony to build a meaningful communication. This phenomenon is also supported by some related recent studies undertaken in Indonesia.

As a response to the problem above, Genre Based Approach is one of alternatives to undertake. This approach is claimed beneficial in accordance with the fundamental aim; that is, to help students produce the text (se Hyland, 2004). This is also supported by the obvious stages
(Emilia, 2011) offered in this approach involving Building Knowledge of Field (BKoF), Modelling of the Text (MoT), Joint Construction of the Text (JCoT), and Independent Construction of the Text (ICoT).

In addition to this, the existence of GBA is a response to the need of explicitness in the teaching through providing the explicit instruction in which a text must be related to its features including social function, text organization and lexico-grammatical features. Specifically, GBA is also hand in hand with the target of the 2013 curriculum as applied in EFL teaching in Indonesia that text-based teaching is a priority to achieve.

Numerous studies related to GBA have been carried out in Indonesia context. 
In these three years, most of them focused still focused on the skill of writing in different types of text (Fauziah,2014; Irianti, 2015). All those studies reported that GBA is effective to develop students' capacity in writing any text types. On the other hand, the research report on GBA in speaking capacity remains limited. Some of the studies (Novianti, 2011; Alawiyah, 2014; Abdullah, 2015) attempted to conduct the studies in Junior High Schools in urban schools. The results of the study confirm that teaching speaking by using GBA is also recommended to do.

Seen from the explanations above, it is safe to say that the studies concerning Genre Based Approach in teaching of speaking in the context of rural schools are still very few. Therefore, it is necessary to conduct the following studies to enlarge the related findings on how GBA develop students' speaking capacity in the special context; rural schools.

Hence, this present study is aimed at examining the effectiveness of Genre Based Approach in teaching speaking of descriptive text in a rural Junior High school in Nusa Tenggara and if any, what improvements are gained by students in their speaking of descriptive text through GBA framework.

In regards with the issue of this study as explained in the previous part, this study attempts to answer two research questions: (1) is GBA effective to develop students' speaking of descriptive text in a rural Junior High School in NTB?; (2) if any, to what extent does GBA develop students'speaking of descriptive text?

\section{LITERATURE REVIEW}

\section{Genre Based Approach}

Systemic Functional Linguistic Genre Based Approach (GBA), firstly appeared in 1980s as the branch concept of SFL by Halliday, is a learning overt instruction pedagogy (Rothery, 1996). Its appearance is based on two reasons; first, a response of the dissatisfaction of the teaching and learning literacy approaches in Australia (Deakin University, 2002), and second, the ignorance of grammatical aspect (Martin, 1999).

Conceptually, GBA inclines the teacher to encourage students' awareness that the text is a unique creation of the author and relative for groups of people in such distinctive context (Hyland, 2004; Emilia, 2011). By this, the students are taught to be critical in building or digesting meaning of text since it has limited area of thought. This is in line with the concept of Systemic Functional Linguistic which focuses on the relationship between text and context.

Further, it is a favor for the implicit language teaching approach that has been widely utilized since GBA deploys explicit instruction in the process of teaching (Feez \&Joyce, 1998; Cope \& Kalantzis, 1993; Emilia, 2011). Explicit teaching does not mean return to the traditional teaching which separate the grammatical aspect from authentic usage. This means, both grammatical and authentic usage are in the same line to be taught. It is assumed that by having explicit instruction, the students incline to get clearer information by means of the essence of teacher's role (Thonburry, 2008).

The crucial role of teacher is respectively on the giving of direct instruction related to the features for the specific communication purpose in such social context due to the needs of understanding explicitly by the interlocutor (Thonburry, 2008; Derewianka, 1997).

GBA provides explanation of how language is functioned in such different purposes systematically (Hyland, 2004) which potentially yields broader ability in using language (Emilia, 2011). It guides the students to count on the specific meaningmaking potential in every particular communication (Halliday, 1994). 
GBA is in the perspective of learning language as a social activity (Feez \&Joyce, 1998). This is in line with learning pedagogy that announced by Vygotsky (1978) and Bakhtin (in Emilia, 2011) which brings the social context such as value. This means, the students are not only focused on learning language, but also learning from language and learning about language (Derewianka, 1997; Feez \&Joyce, 1998).

In regard with Hyland (2004), there are five traits of GBA. First, it is a visible pedagogy (Martin, 1999) that discloses what learners need to learn and how they will be assessed. Second, it is drawn on Systemic Functional Linguistics to show how specific linguistics choices relating to the context of use and to the language system in general. Third, it sees teaching as assistance that supports learners' evolving abilityto create meaning during language activity; this assistance occurs through "interaction in the context of shared experience" (Martin, 1999: 126). Fourth, it sees teaching as an intervention to empower students for accessing, understanding, and challenging valued texts (Martin, 1999). Fifth, the GBA aims to increase learners' and teachers' awareness of how text works.

As the end of the process, productivity of the students is the result of whole phases of GBA. Particularly, the product must be in terms of not only writing but also speaking. It is depicted by the assessment in GBA that focus on productivity of the students that embraces two factors; generic structure and linguistic features of students' work in written or spoken.

As the base, the students are set to conduct the listening and reading comprehensively in the beginning of the activity since the role of teacher is still dominant in fulfilling the students' former background knowledge. This means that both receptive skills are preserved in absorbing the rudimentary theory of the genre given.
These are respectively utilised because the absorbed theory has a great influence toward reaching the goal of teaching and learning process through GBA.

The vary of GBA model have been launched, but firstly launched, the model had only three learning cycles; modeling, joint constuction and independent construction. This model has been modified by the additional of preparation phase as suggested by Derewianka (1997) and negotiating field and deconstruction (Rothery, 1996) or building knowledge of field which is proposed by Feez (1998).

In relation to Indonesian curriculum, English curriculum has been applying rothery's model which has four cycles. At the beginning, negotiating field is the process whereby knowing the need, topic and content is becoming the priority. For instance, the teacher should digest the students' background knowledge related to the topic. By this process, the teacher can actually choose which part of the material which is the most important to be taught.

Continue to the second phase, there is deconstruction which considers the two essential components of the text; context of culture/ situation and text. In context of culture, the students are askes to find the social purpose of the text. Additionally, field, mode, and tenor are questioned to find its context of situation. In another division of deconstruction, the textuality is the process that focuses on the function of the text, the name of language feature used, the text about, and the relationship between the writer and the reader.

In the third part, there are two division as in the second stage; preparation and construction. How do prepare the joint reconstruction in the text such as by building up field information through research and using guidance questions to scaffold activities, one of which is observation. In 
the conctruction process, the students are asked to jointly construct a new text with the same genre.

In the last part, independent construction, the biggest division, has three parts including preparation, consultation with teacher or friends, and critical literacy. As a preparation, the students do the same thing as preparation in joint construction. In a consultation part, the students are asked to arrange a text individually. They are also allowed to acquire a consultation during and after writing which is ended by editing process and evaluation of their writing. Further, in critical literacy, students utilise genre to challenge ideology, theory and practice.

Popularly used in Indonesian context, Martin's model has four stages; building knowledge of field, modelling, joint construction of text and independent construction of text. Basically, eventhough the pictures of Rothery's model and Martin's model are different, the concept are almost the same by considering four aspects; building the students knowledge about the field, giving model that can be put as reference, working in team and drafting and revising individually.

Technically, genre based approach is an approach for teaching and learning process that provides the teacher with a set of four-stage-process; building knowledge of field, modelling of text, joint construction of text, and independent construction of text. Basically, the four processes are classified into two types of skills; receptive (BKoF and MoT) and productive (JCoT and ICoT). Orderly conducted, the steps are aimed at creating student's self-consciousness in thinking critically toward every problem given (Hyland, 2004). The autonomous response of thinking critically is triggered by the instructions existed in every level of genre-based approach teaching and learning process.
Firstly, in the building knowledge of field, the students are given a set of material foundation.Secondly, in the modelling of text phase, the students are a means of a good copier since what they have to do is monitoring every distinctive model of one type of text and saving it. Thirdly, the students and the teacher are co-creating a new text of the studied genre(Martin, 1999).

As in line with the theory, Martin (1999) \& Wenger (2000)point out that basic foundation of learning is the idea of guidance through sharing experience interaction in the context; engaging in joint activities, discussions, mutual help, sharing of information, i.e. in learning together. Further, Wenger (2000: 229) argued that it is at the very core of what makes us human beings capable of meaningful knowing.

Knowledge about language is thus first mediated inter-mentally and then appropriated and internalized by the individual. This means that learning does not happen outside performance (after implementing comprehensible input) but occurs in performance and as such it is cumulative, emergent and ongoing. Additionally, it corresponds with the genre theory as it emphasizes the notion of learning a language as learning to make meaning and behave in the world in another way. If students cannot mean and behave in a new culture through its texts and language, they cannot interact successfully.

The last step, independently the students arrange the same genre on their own. After they are assumed to be eligible in group work, the new text should be finished individually. They are explicitly encouraged to creatively exploit the genre and its possibilities gradually claiming its control. The assumption related to the readiness of the students to do the task without any support from their friends is the point that need to be considered since it may relate to the mental aspect of the 
students influencing their performance in composing the text. Thus, this last stage of GBA preserves the students to be mature in creating the typical text.

Put differently, all of those four stages above should be undertaken orderly and completely to achieve the maximum goal in the text based teaching. Additionally, this should be noticed that these have the same proportion in either writing or speaking as the output.

\section{Teaching Speaking}

Speaking is a crucial part of second language learning and teaching. Despite its importance, for many years, teaching speaking has been undervalued and English language teachers have continued to teach speaking just as a repetition of drills or memorization of dialogues. However, today's world requires that the goal of teaching speaking should improve students' communicative skills, since, only in that way, students can express themselves and learn how to follow the social and cultural rules appropriate in each communicative circumstance. More importantly, English speakers, particularly whose English is their second or third language, need to be able to speak in various contexts properly.

To this relation, Nunan (2003) highlights that what is meant by teaching speakingistoteachEnglishlanguage learners to: (1) produce the English speech sounds and sounds patterns; (2) use words and sentence stress, intonation patterns and the rhythm of the second language; (3) select appropriate words and sentences according to the proper social setting, audience, situation and subject matter; (4) organize their thoughts in a meaningful and logical sequence; (5) use language as a means of expressing values and judgments; (6) use the language quickly and confidently with few unnatural pauses, which is called fluency.

Regarding Brown (2004: 271), there are six categories of speaking skill area. Firstly, imitative. It includes the ability to practice an intonation and focusing on some particular elements of language form. Secondly, intensive. This is the students' speaking performance that is practicing some phonological and grammatical aspects of language. Thirdly, responsive. Responsive performance includes interaction and test comprehension but at the somewhat limited level of very short conversation, standard greeting and small talk, simple request and comments.

Fourthly, transactional (dialogue). It is carried out for the purpose of conveying or exchanging specific information. Fifthly, interpersonal (dialogue). It is carried out more for the purpose of maintaining social relationships than for the transmission of facts and information. Sixth, extensive (monologue). The extended monologues are given by teacher in the form of oral reports, summaries, and story-telling and short speeches.

\section{RESEARCH METHOD}

This study used post- test only quasi experimental design in which there are two classes called experiment class consisting participants who got special treatment and control group who roles as the comparison to the treatment one (Creswell, 2010). In addition to this, the comparison is between the post-test result of experimental group and one shot test result of the control group. In addition to this, qualitative research design in form of case study to see the students' improvement in speaking through GBA was chosen for some consideration. First, the data were gained in natural setting (Bogdan \& Biklne, 1992) in which focused on the analysis of the students' script of their speaking. Second, the study was undertaken in the small scale without any intention to generalize beyond the case (Creswell, 2010), in line with this, the result of the qualitative analysis working on the 
second research question is not aimed at generalizing the findings.

Setting of study is one of Islamic rural schools in Nusa Tenggara Barat was chosen as the site of this study for some reasons. Eighty students categorized as treatment and control group served as the participants. They are from eight grade who learn descriptive text based on the given syllabus. Specifically, only six students served as the focused participants to answer the second research question in qualitative design. They were purposively chosen based on the level of achievement of their speaking score from the teacher into; high, mid, and low categories. Additionally, as the profile of the teacher who conducted GBA, this teacher is a male teacher who has 8 year experiences in teaching.

There are two instruments used in this study covering; observations and students' speaking test.This observation was aimed at investigating how the teacher applied the concept of GBA in the teaching of descriptive text. Another instrument used is students' speaking tests involving the test of experimental group as well as the control group. This instrument basically functions to examine whether or not GBA could develop students' speaking capacity of descriptive text.

This phase elaborates the teaching program as the intervention conducted in this study. Firstly, Building Knowledge of Field (BKoF). The teacher used 2 meetings to build students' knowledge of the topic. Secondly, Modelling of the Text (MoT). Two meetings were also taken in this stage. This modelling phase was conducted through giving three text models to students, such as: (1) text was used to introduce the content of the text in which students were only guided to answer some related questions on the text; (2) the second text model was utilized to introduce generic structure and linguistic features of descriptive text; (3)
Joint Construction of the Text (JCoT). The teacher only used the step of joining to construct text in groups. Specifically, the students were divided into several groups. Fourthly, Independent Construction of the Text (ICoT). Every student was asked to make a spoken descriptive text, starting from making the script of the text, consulting to the teacher, then performing it in form of monologue speaking in front of class.

Due to the use of quantitative and qualitative approaches, this study also two types of data analysis: (1) the data were quantitatively analyzed using t-test through SPSS; (2) the data were qualitatively examined using inductive analysis (Emilia, 2011). The process of collecting the data started from August, 2017. After getting the permission from the school to undertake the study, there were some stages to carry out: (1) conducting pre-interview with the teacher about the concept of GBA; (2) doing classroom observations to investigate the process of teaching descriptive text using GBA. Third, recording the speaking test of students at the end of the GBA stage (ICoT) in experimental group. Fourth, giving the speaking test of descriptive text to the control group.

\section{FINDINGAND DISCUSSION}

\section{The Effectiveness of GBA in Developing Students' Speaking of Descriptive Text}

Based on the statistical calculation used in this study comparing students' speaking score between experimental and control group, the result reveals that Genre Based Approach is effective to develop students' speaking of descriptive text. This finding is gained from t-test as the tool used to proceed the data. Moreover, the details of the statistical result is presented in the following sub-sections.

This subsection reports the students' speaking score of experimental group (those who got GBA treatment) and the 
control group (those who did not get any intervention). The result of post-test in experimental group.

\section{Table 1}

\section{Students' Speaking Score of Experimental Group}

\begin{tabular}{ccc}
\hline No & $\begin{array}{c}\text { Initial } \\
\text { name }\end{array}$ & Score \\
\hline 1 & AL & 70 \\
\hline 2 & HK & 75 \\
\hline 3 & SR & 75 \\
\hline 4 & PR & 85 \\
\hline 5 & AY & 90 \\
\hline 6 & SL & 85 \\
\hline
\end{tabular}

\begin{tabular}{ccc}
\hline No & Initial & Score \\
& Name & \\
\hline 7 & AR & 90 \\
\hline 8 & GL & 75 \\
\hline 9 & RD & 75 \\
\hline 10 & YS & 90 \\
\hline 11 & EL & 85 \\
\hline 12 & EG & 90 \\
\hline
\end{tabular}

Table 2

The result of one-shot test in control group

\begin{tabular}{ccc}
\hline No & Initial name & Score \\
\hline 1 & AD & 75 \\
\hline 2 & RT & 65 \\
\hline 3 & CF & 65 \\
\hline 4 & GW & 65 \\
\hline 5 & DG & 75 \\
\hline 6 & BN & 80 \\
\hline 7 & FR & 65 \\
\hline 8 & HL & 70 \\
\hline 9 & LP & 70 \\
\hline 10 & LU & 65 \\
\hline
\end{tabular}

\section{Chart 1}

The Comparison of Post Test Score

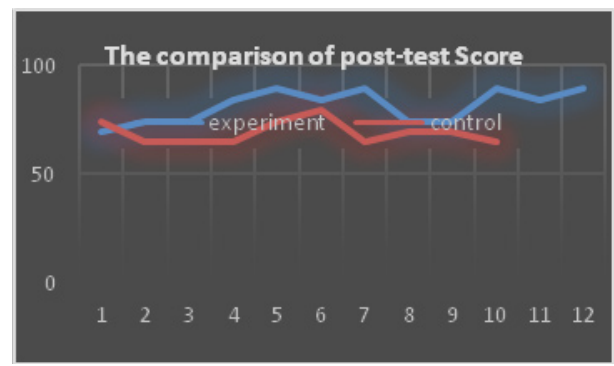

The chart above shows that the score of students' speaking of descriptive text in experimental group is higher than those who were in control group. Specifically, the lowest score in experimental group is 70 while 65 is the lowest one in the control group. Additionally, the students in experimental group could achieve 90 while in control group, the highest score is 80 .

In this study, Kolmogorov-Smirnov is utilized in examining the normal distribution of post test score. Moreover, the data is presented on the table below.

Tabel 3:

Tests of Normality ${ }^{\mathrm{c}, \mathrm{d}, \mathrm{e}, \mathrm{f}}$

\begin{tabular}{|c|c|c|c|c|c|c|}
\hline & & \multicolumn{3}{|c|}{$\begin{array}{c}\text { Kolmogorov- } \\
\text { Smirnov }^{\mathrm{a}}\end{array}$} & \multicolumn{2}{|c|}{ Shapiro-Wilk } \\
\hline & & Statistic & Df & Sig. & Statistic df & Sig. \\
\hline experiment & 65 & .254 & 5 & $.200^{*}$ & .803 & .086 \\
\hline control & 75 & .260 & 2 & $\cdot$ & & \\
\hline
\end{tabular}

As the detail in the table above, the data are normally distributed leading to the parametric hypothesis testing as appropriate way to analyze the data. Particularly, the criteria of normal distribution are seen from the significance point of the presented on the table. It is acquired that the significance (0.200) is higher than 0.05 .

This part elaborates the result of t-test calculation in processing the data. Previously, the hypothesis as examined in this study is formulated below.

Null hypothesis, there is no difference of post test result between experimental and control groups in speaking of descriptive text. In contrary, alternative hypothesis: there is difference of post test result between experimental and control groups in speaking of descriptive text.

Table 4

Group Statistics

\begin{tabular}{cccccc}
\hline & Class & N & Mean & $\begin{array}{c}\text { Std. } \\
\text { Deviation }\end{array}$ & $\begin{array}{c}\text { Std. Error } \\
\text { Mean }\end{array}$ \\
\hline \multirow{2}{*}{ Score } & A & 12 & 82.0833 & 7.52521 & 2.17234 \\
& B & 10 & 69.5000 & 5.50252 & 1.74005 \\
\hline
\end{tabular}


Tabel 5

Independent Samples Test

\begin{tabular}{|c|c|c|c|c|c|c|}
\hline \multicolumn{7}{|c|}{ t-test for Equality of Means } \\
\hline $\mathrm{t}$ & $\mathrm{df}$ & $\begin{array}{c}\text { Sig. } \\
(2-\text {-tailed })\end{array}$ & $\begin{array}{c}\text { Mean } \\
\text { Difference }\end{array}$ & $\begin{array}{c}\text { Std. Error } \\
\text { Difference }\end{array}$ & \multicolumn{2}{c|}{$\begin{array}{c}\text { 95\% Confidence } \\
\text { Interval of the } \\
\text { Difference }\end{array}$} \\
\cline { 5 - 7 } & & & & & Lower & Upper \\
\hline 4.392 & 20 & $\mathbf{. 0 0 0}$ & 12.58333 & 2.86496 & 6.60714 & 18.5595 \\
4.521 & 19.72 & .000 & 12.58333 & 2.78332 & 6.77217 & 18.3945 \\
\hline
\end{tabular}

The tables above show that the values of post-test between experimental and control groups are different. Specifically, it is gained that $\mathrm{F}=3.675>0.05$ so the data are homogeny. Then, $\mathrm{t}$ critical $=-4.392<0.05$. it means that the score lies out of the accepted area in null hypothesis. Therefore, Ho is rejected while Ha is accepted. Hence, it is concluded that there is difference between students' post test score in experimental group and in control group. In other words, GBA is effective to apply in developing students' speaking of descriptive text.

\section{The Improvement of Students' Speaking of Descriptive Text}

This sub-section elaborates the qualitative data regarding the improvement as gained by the experimental group in speaking of descriptive text. In this study, there are three students covering one high, one mid-and one low achievers as the subject of this study whose texts are analyzed.

In terms of social function, all participants could achieve the aim of their descriptive texts in the final test; that is, to describe someone. As an example, the low achiever (AL) could clearly state the object he would like to describe at the beginning of his speech (in identification part). Additionally, this is also followed by some descriptions he gave in the following stage of this descriptive text. This improvement is very different from his previous spoken text in the pre-test in which he did not explain clearly about the one whom he described, even he appeared another person to discuss which makes the focus of the description is not obvious. This is shown as what he had written" He has a brother named Fatir, Fatir is fat too, He is kind. ". Put differently, AL's pre-test failed to describe the focus figure as what has to be highlighted in a descriptive text.

In addition to this, the medium student (EG) also shown his improvement in showing the purpose of his text. Previously in the pre-test, he only described the figure in general; that is, international Ustadz. Although he was quite good in using dialogic statement "do you know him", this leads a problem since he had to describe the figure clearly, not by making audience guess whom he described. In addition to this, his text also does not mention in the early part what will be described; the aspects of someone's physics, someone's achievements, carriers or others. Therefore, thisproblem led to bring out the unclear focus of the description he offered.

However, after GBA was undertaken for eight meetings, he could fix his mistake; that is, by focusing on one clear figure he described about; that is, Dr. Zakir Naik as "He is my second idol after my prophet muhammad saw. His name is Dr. Zakir Naik". Moreover, in the initial part, he also mentioned that he would describe the physical appearance of his favorite Ustadz as in "do you know him? Have you heard his name? Now look at to the picture!". From the post test, it is seen that this student had been aware of the importance of the clarity in his descriptive text which should be shown from the beginning part. Another progress of his text is that he had been able to steer the focus of his text by using dialogic statements, helping audience to understand what will be concerned in the text.

Moving to the high achiever, RD, he basically had been well in mentioning the focus of his text in the pre-test; that is, about Vin Diesel as an artist in a film, "He is artist of tripple $x$ film and fast furious film". 
However, he had some missed information when he wrote "He is the rider the legend of rider especially car." The second statement as shown above points out that Diesel is a rider instead of the fact that being a rider is solely fictional in that film. This means that he was not careful in conveying the information.

Different from his pre-test, RD was successful to place the focus of his descriptive genre. The statements of" do you know the fast furious film? In this film, he is the rider the legend of rider especially car" show that his emphasis is on Diesel as the artist who took a role as the rider in the film. This such improvement automatically increases the quality of descriptive text he delivered to.

From the explanation above, it is concluded that all students were successful to point the clear aim of the descriptive text; to describe particular things/ people. This is in line with Knapp \& Watkins (2005); Emilia (2011) and Hyland (2004) that descriptive texts functions to describe someone/something.

As mentioned in the related theories, descriptive text commonly consists of two parts' they are, identification and description (see Derewianka \& Jones, 2012; Thai, 2009). Seeing this, all three participants could fulfill those two stages in their descriptive text. As an evidence, the low achiever (AL) could separate the part of identification and description. This result is distinctive with the spoken text he made in the pre-test in which he combined the part of identification and description. Below is the difference of his introduction part in the pre-test and post-test.
Tabel 6

Intro. In Pre-Test and Post-Test

\begin{tabular}{|c|c|}
\hline (pre-test) & (post-test) \\
\hline Haikal & Now, I would like to \\
\hline He was one of my & describe someone \\
\hline classmates & I will choose Haikal \\
\hline He came from & He..... \\
\hline Lombok.. & \\
\hline
\end{tabular}

From the table above, it is seen that this participant could structure the text better in the post-test since he fronted the introduction (identification) before he was going to describe the person in details.

The other participants also proved their improvements in structuring their text. First, AL could not make parallel structure in describing someone; as an example, His face is chubby and white skin. However, he could show the betterment in the description part in which he could position some words regarding the types of speech; as an instance, 'His face is chubby and his nose is wide". Second, EG also spoke the descriptive text better in terms of the text organization. Previously, he could not structure the general part of description and the specific one. However, in the post test. He could organize the text well in which description of someone in details are given after the subject is introduced in the beginning part of the text.

Seeing the data above, it is inferred that most of students had understood the organization of descriptive text as proposed by the scholars (Derewianka \& Jones, 2012; Emilia, 2011; Thai, 2009). In addition to this, the result also confirms the previous related studies as conducted by (Emilia, 2011) that Genre Based Approach contributes to developing students' capacity in understanding the genre concept into communication.

In terms of linguistic features, almost all participants have progress in putting the correct features of the grammar in their 
spoken descriptive text. As an example, AL put so many adjectives in his spoken text (chubby, wide, oval, short, big, and straight). Similar to his text, EG also could use more adjectives to describe his favorite figure (chubby, thick, small, short). These findings are also ones of the improvements since both of these participants were not aware enough of the importance of adjectives in their previous descriptive text.

In line with this, it is seen that the students' text in the final test is categorized sufficiently good in terms of using so many related adjectives in the text. This is in consonant with the theory that adjectives are necessarily put in describing people/ things (Thai, 2009).

The next lexico-grammar in descriptive text is present tense. The post test result shows that all participants used present tense in describing people. This is also different from the pre-test result, specifically, EG and RD used past tense to describe someone in the present condition as shown below.

\section{Tabel 7}

\section{EG and EG in Pre-Test and Post-Test}

\begin{tabular}{|c|c|}
\hline Pre-test (EG) & Post- test (EG) \\
He had a wide nose & He has a wide nose \\
\hline
\end{tabular}

Furthermore, the low achiever also could show the improvement in using correct tense in describing person.

\section{Tabel 9}

\section{$A L$ and $A L$ in Pre-Test and Post-Test}

\begin{tabular}{|c|c|}
\hline $\begin{array}{c}\text { Pre-test (AL) } \\
\text { He was one of my } \\
\text { classmates }\end{array}$ & He is one of my classmates. \\
\hline
\end{tabular}

Seen from two evidences above, it is safe to say that students have better understanding on using the tense as reflected in their descriptive text. This conclusion is also hand in hand with (Emilia, 2011; Knapp \& Watkins, 2005) that present tense is one of lexico-grammatical features when we aim to describe things/persons.
Another linguistic feature of descriptive text is using specific participant. In this aspect, all students have put the specific participant in their text (Zakir Naik, Haikal, Vin Diesel). This is in consonant with Derewianka \& Jones (2012) that one of characteristics of descriptive text differing from report text is the use of specific participant.

To conclude, students shown the improvementin putting the complete features in lexicon-grammar in their descriptive text after they learnt that text under Genre Based Approach. This conclusion is also in keeping with other previous studies (Novianti, 2011; Abdullah, 2015) that GBA could improve students' capacity in speaking including the aspect of linguistic features.

\section{Additional Findings}

Out of the findings as reported in the previous subsection, this part provides some additional evidences as seen from this study as presented below.

1. Most of students still could not enrich their descriptive text. They only focused on telling someone's description in the side of physics. However, descriptive does not solely deal with physical appearance, it can be widely directed to someone's carrier, achievement, and others.

2. In terms of students' general speaking capability as measured by SOLOM, many students had poor pronunciation in conveying particular words. Even, almost all students who performed their monologue speaking of descriptive text made errors in pronunciation. This data brought about to the conclusion that the teacher only focused on the concept of the text; social function, generic structure and linguistic features without paying attention sufficiently on controlling students' pronunciation. 
3. Students have started to understand the characteristics of spoken language. One of evidences is that some of students used dialogic text to show or stimulate the communicativeness with the audiences. Below is an example of the dialogic text which students utilized.

\section{Tabel 10}

EG and RA in Pre-Test and Post-Test

\begin{tabular}{|c|c|}
\hline (EG) & (RA) \\
His name is Dr. & Do you know him? \\
Zakir Naik & What is his name? \\
Do you know him? & \\
\hline
\end{tabular}

4. From the text analysis, it is seen that the teacher had lack of giving corrective feedback to students, particularly in terms of the aspect of pronunciation as the general part of speaking. Seeing this, corrective feedback is claimed important in teaching and learning process since it helps students to be aware of their errors and encourage them to understand the correct ones.

5. From some minor errors found in the students' text, teacher also missed the stage of constructing the text together with students in JCOT. In this study, the teacher directly asked students to join constructing the script of descriptive text. However, in accordance with Emilia (2011), the step when the teacher, together with students, construct a text in JCoT is assumed important to undertake, especially for the students who are categorized mid- to low. This is reasonable since students in this category will need more guidance step by step to achieve the targeted aim.

\section{CONCLUSION}

GBA is effective to apply in teaching students' descriptive text. This result is based on the statistical calculation using t-test showing that null hypothesis is rejected while alternative hypothesis is accepted.
These data depict that GBA reflects its effective practice to teach spoken descriptive text. Then students' improvement in their speaking of descriptive text is seen from the aspects of genre involving social function, text organization and lexicon-grammatical features of descriptive text. It means that all focus-participants fulfilled almost all components needed in constructing descriptive text.

\section{REFERENCES}

Abdullah, Cep Ubad. 2015. Genre-Based Approach to Teaching Speaking: A Case Study at a State Junior High School in Bandung. S2 Thesis, Universitas Pendidikan Indonesia. $\mathrm{http} / /$ :repositori.upi.edu/20482/.

Alawiyah,Tuti.2014.TheUseofGenreBased Approach in Teaching Speaking: a Case Study at Junior High School in Bandung Barat Regency. S2 Thesis, Universitas Pendidikan Indonesia. $\mathrm{http} / /$ :repositori.upi.edu/13232/.

Brown, D.H. 2004. Language Assesstment: Principles and Classroom Practices. New York: Longman.

Cope,B., \& Kalantzis, M. 1993.Introduction: How a Genre Approach to Literacy can Transform the Way Writing is Taught.' In Cope, B. and Kalantzis, M. (1993). (Eds). The Powers of Literacy. A Genre Approach to Teaching Writing. London: The Falmer Press.

Creswell, J. W. 2010. Educational Research: Planning, Conducting, and Evaluating Quantitative and Qualitative Research. California: Pearson Education, Inc.

Derewianka, B. 1997. Exploring How Text Works. Sydney: Primary English Teaching Association. 
Derewianka \& Jones. 2012. Teaching Language in Context. Melbourne: Oxford University Press.

Emilia, Emi 2011. Pendekatan Genrebased Approach dalam Pengajaran Bahasa Inggris: Petunjuk Bagi Guru. Bandung: Rizqi Press.

Fauziah, A. N. 2014. Genre-based Approach to Teaching Writing Report Text. S2 Thesis. Universitas Pendidikan Indonesia. http//:repositori.upi.edu.

Feez, S. 1998. Text-based Syllabus Design. Sydney: National Centre for English Language Teaching and Research.

Feez, S. \& Joyce, H. 1998. Text-Based Syllabus Design. Sydney National Centre of English Language Teaching and Research, Macquire University.

Halliday, M. A. K. 1994. An Introduction to Functional Grammar. (2nd Ed). London, Edward Arnold.

Harmer, J. 2007a. The Practice of English Language Teaching. Malaysia: Pearson Education.

Hyland, K. 2004. Genre and Second Language Writing. Ann Arbor: University of Michigan Press.

Irianti, Ira 2015. Genre-based Approach to Teaching Writing Descriptive Text. S2 Thesis. Universitas Pendidikan Indonesia. http//:repositori.upi.edu.

Knapp, P. \& Watkins, M. 2005. Genre, Text, and Grammar. Sydney: UNSW Press Book.

Martin, J. 1999.Mentoring Semogenesis: 'Genre-based' Literacy Pedagogy. In F. Christie (Ed.). Genre in The Classroom: Multiple Perspectives (pp.17-42). Mahwah, NJ; London: Lawrence Erlbaum Associates.

Martin, J. 2009. Genre and Language Learning: A Social Semiotic
Perspective. Linguistics and Education, Vol.20, pp. 10-21.

Novianti, Rully R. 2011. Developing Students' Speaking Ability through Genre-Based Teaching: Action Research with the First Year Students in A Senior High School. S2 Thesis, Universitas Pendidikan Indonesia. http://repository.upi.edu/10020/.

Nunan, D. 2003. Practical English Language Teaching. New York: McGraw-Hill.

Rothery, J. 1996. Making Changes: Developing an Educational Linguistics. In R. Hasan G. Williams. (Eds.) Society Is Enjoy Science (pp. 86-123) London: New York: Longman.

Thai, M. D. 2009. Text-Based Language Teaching. St Cecil Hills: Mazmania Press.

Thornbury, S. 2008. How to Teach Grammar. Essex: Pearson Education Limited.

Vygotsky, L.S. 1978. Mind in Society. Cambridge. MA: Harvard University Press.

Wenger, E. C. 2000. Communities of Practice and Social Learning System. Organization, Vol.7/2, pp. 225-246. 